\title{
An expeditious construction of 3-aryl-5-(substituted methyl)-2- oxazolidinones: a short and efficient synthesis of Linezolid
}

\author{
Rajesh Tammana, ${ }^{\text {a,b }}$ Kiran Kumar Vemula, ${ }^{a}$ Ramadasu Guruvindapalli, ${ }^{a}$ \\ Ramesh Yanamandra, ${ }^{c}$ and Madhusudhan Gutta*a
}

${ }^{a}$ Department of Research \& Development, Inogent Laboratories Pvt. Ltd., A GVK BIO Company, 28A, IDA, Nacharam, Hyderabad 500 076, Andhra Pradesh, India ${ }^{b}$ Centre for Pharmaceutical Sciences, Institute of Science and Technology, Jawaharlal Nehru Technological University, Hyderabad 500 072, Andhra Pradesh, India ${ }^{c}$ Department of Analytical Research \& Development, GVK Biosciences Pvt. Ltd., 28A, IDA, Nacharam, Hyderabad 500 076, Andhra Pradesh, India

E-mail: madhusudhan.gutta@inogent.com

DOI: $\underline{\text { http://dx.doi.org/10.3998/ark.5550190.0013.605 }}$

\begin{abstract}
A short, concise and efficient synthesis of Linezolid was accomplished through a convergent scheme utilizing either $(S)$-1-azido-3-chloropropan-2-yl chloroformate or $(S)$-1- phthalimido-3chloropropan-2-yl chloroformate as a key starting material. The synthesis demonstrates utility of (S)-1-azido-3-chloropropan-2-yl chloroformate and/or (S)-1-phthalimido-3-chloropropan-2-yl chloroformate to facilitate the expeditious construction of 3-aryl-5-(substituted methyl)-2oxazolidinones and offers the possibility of accessing related 2-oxazolidinone members easily as well as making additional analogues of Linezolid.
\end{abstract}

Keywords: $(S)$-1-Azido-3-chloropropan-2-yl chloroformate, $(S)$-phthalimido-3-chloropropan-2yl chloroformate, linezolid, chloroformylation, 3-aryl-5-(substituted methyl)-2-oxazolidinone

\section{Introduction}

Oxazolidinones represent a milestone in antibacterial research as they represent the first new class of antibiotics to enter clinical usage within the past 30 years. As of 2011, Linezolid (Zyvox®, Pfizer, Figure 1) represents the first antibacterial with a new mechanism of action approved by the U.S. Food and Drug Administration (FDA). ${ }^{1}$ Linezolid has excellent in vitro activity against all of the major Gram-positive bacteria that are pathogenic to humans., Linezolid has been approved for the treatment of patients with community-acquired and nosocomial pneumonia, complicated skin and soft tissue infections and infections due to vancomycin-resistant Enterococcus faecium, or for the treatment of heteroresistant vancomycin- 
intermediate Staphylococcus aureus and penicillin-resistant pneumococci. ${ }^{4-6}$ Others of this class have entered development, such as Rivaroxaban (Bay-59-7939), ${ }^{7}$ Ranbezolid (RBx 7644), ${ }^{8}$ Posizolid (AZD 2563), ${ }^{9}$ Torezolid (TR-701), ${ }^{10}$ and Radezolid (RX-1741). ${ }^{11}$

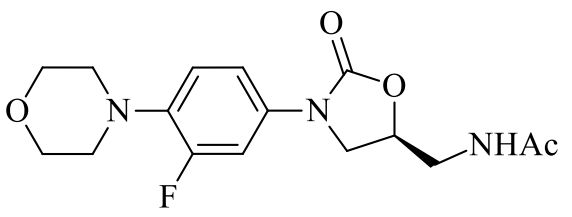

Linezolid (Zyvox®), 1

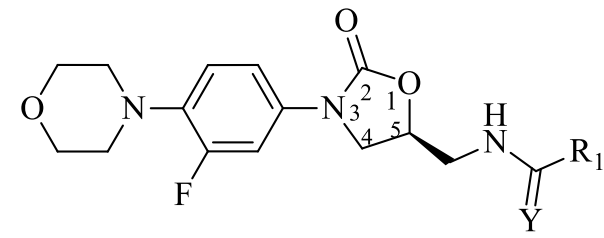

$\mathrm{Y}=\mathrm{O}$ or $\mathrm{S} ; \mathrm{R}_{1}=-\mathrm{NH}_{2}, \mathrm{OCH}_{3}$ or $\mathrm{CH}_{3}$ etc

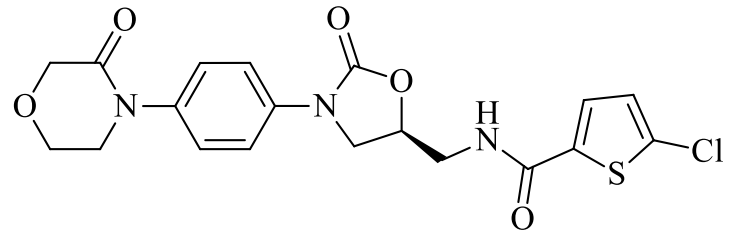

Rivaroxaban (Bay-59-7939)

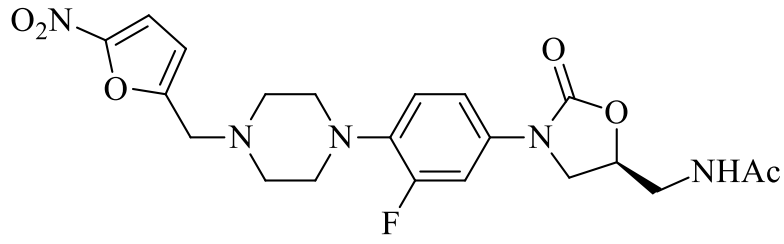

Ranbezolid (RBx 7644)

C-5 substituted 2-Oxazolidinones

Figure 1. Various 3-aryl-5-(substituted methyl)-2-oxazolidinones.

In this context, the reported syntheses of Linezolid [3-aryl-5-(substituted methyl)-2-oxazolidinone] require mention. For instance, the classical method involves conversion of 3-fluoro-4morpholinobenzenamine $\left(\mathrm{ArNH}_{2}\right)$ to corresponding carbamate which is deprotonated with $n$ BuLi or lithiumdiisopropyl amide (LDA) in THF followed by reaction with 2-substituted oxirane at $-78{ }^{\circ} \mathrm{C}$, or in another method, the aryl carbamate was reacted with 1-substituted 3chloropropan-2-ol (halohydrin) using lithium $t$-butoxide ( $\mathrm{LiO} t \mathrm{Bu}$ ) or $n$-BuLi to generate $(R)$-3aryl-5-(hydroxymethyl)-2-oxazolidinones. These 3-aryl-5-(hydroxymethyl)-2-oxazolidinone intermediates are elaborated to final products. ${ }^{12,13}$ However, in these methods for the synthetic key step to 2-oxazolidinone ring, severe conditions with low temperature $\left(-78{ }^{\circ} \mathrm{C}\right)$ and an airsensitive base $(n-\mathrm{BuLi})$ are required, which limit the large-scale production in the industry. Other described synthetic methods involving aryl isocyanate instead of aryl carbamate are effective, but not general. The preparation of aryl isocyanates is cumbersome from multi-substituted aryl amines. Moreover, while preparing aryl isocyanates a major concern is the formation of the corresponding urea as a significant impurity. ${ }^{14}$

On the other hand, oxirane ring opening of 2-substituted oxirane using 3-fluoro-4morpholinobenzenamine and carbonylation followed by further functional group transformations gave the Linezolid. ${ }^{15}$ One more method involves the conversion of $(R)$-1-azido-3-chloropropan2-ol (halohydrin) to corresponding carbonate derivative followed by reaction with $\mathrm{ArNH}_{2}$ giving required 2-oxazolidinone. ${ }^{16}$ In addition, there are some other articles describing the construction 
of 5-(substituted methyl)-2-oxazolidinone followed by coupling with aryl halide using various reaction conditions and further transformations leading to Linezolid formation. ${ }^{17,18}$

The latest analogs have common functionalities on the C-5 aminomethyl group, such as acetamides, carbamates, ureas, thioamides, thiocarbamates, and thioureas (Figure 1). ${ }^{19}$ During the conversion of amines to acetamides, carbamates, ureas, thioamides, thiocarbamates, and thioureas, there is a higher chance of obtaining the corresponding symmetrical derivatives.

\section{Results and Discussion}

In view of these limitations for accessing related 2-oxazolidinone members easily as well as making additional analogues of Linezolid and our interest in developing the small chiral building blocks, ${ }^{17}$ herein we wish to report the synthesis of novel chiral synthons, $(S)$-1-azido-3chloropropan-2-yl chloroformate 3a or $(S)$-phthalimido-3-chloropropan-2-yl chloroformate 3b by phosgenation of corresponding chlorohydrin with triphosgene (Scheme 1) and demonstrated their application in the synthesis of Linezolid (Figure 2). One of the early methods in the synthesis of 2-oxazolidinones involves the reaction of phosgene and aniline with $\beta$-chloroethanol to produce $\beta$-chloroethyl- $N$-phenyl carbamate which is cyclized by boiling in potassium hydroxide solution. ${ }^{20}$ However, this methodology is not well utilized in synthetic organic chemistry and drug discovery probably due to the fear of limited (low) stability of 1-chloroalkan-2-yl chloroformates. Providentially, compounds $\mathbf{3 a}$ and $\mathbf{3 b}$ are quite stable for several days in the reaction condition and even after isolation.

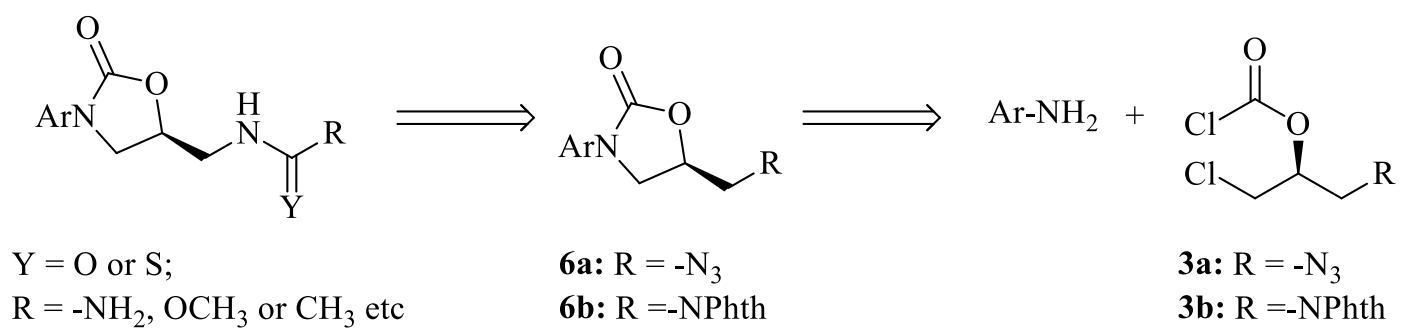

Figure 2. Application of (S)-1-azido-3-chloropropan-2-yl chloroformate 3a and (S)-1phthalimido-3-chloropropan-2-yl chloroformate $\mathbf{3 b}$ in the synthesis of 3-aryl-5-(substituted aminomethyl)-2-oxazolidinone.

Accordingly, $(S)$-epichlorohydrin was stereoselectively ring-opened with either $\mathrm{NaN}_{3}$ or phthalimide to give corresponding chlorohydrin $\mathbf{2}$. The chlorohydrin $\mathbf{2}$ on treatment with triphosgene using triethylamine as a base in tetrahydrofuran gave corresponding chloroformate $\mathbf{3}$. It is worthwhile to mention that under these conditions $(S)$-1-azido-3-chloropropan-2-yl chloroformate 3a and (S)-1-phthalimido-3-chloropropan-2-yl chloroformate $\mathbf{3 b}$ are quite stable and isolated readily without a trace of the corresponding chloride or symmetrical carbonate. 


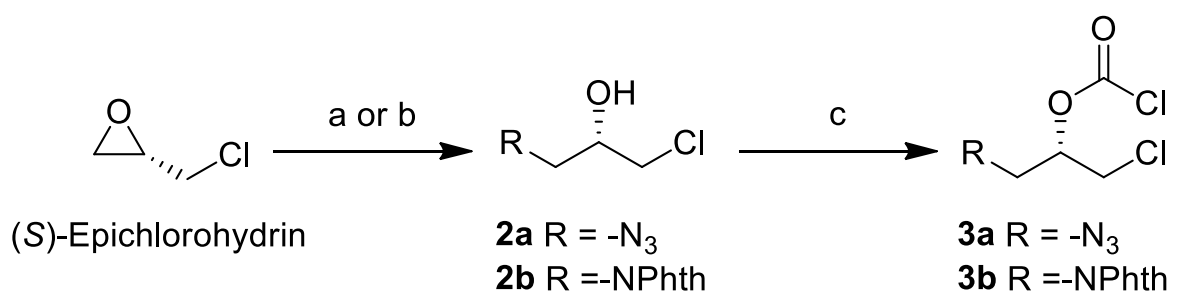

Reagents and conditions: (a) $\mathrm{NaN}_{3}, \mathrm{AcOH}, \mathrm{H}_{2} \mathrm{O}$, ambient temperature, $5 \mathrm{~h}, 80 \%$; (b) Phthalimide, $\mathrm{K}_{2} \mathrm{CO}_{3}$ (cat.), IPA, reflux, $5 \mathrm{~h}, 75 \%$; (c) Triphosgene, Et $3 \mathrm{~N}$, THF, $0{ }^{\circ} \mathrm{C}$ to r.t., $2-3 \mathrm{~h}$, $72-89 \%$.

Scheme 1. Preparation of (S)-1-azido-3-chloropropan-2-yl chloroformate 3a and (S)-1phthalimido-3-chloropropan-2-yl chloroformate $\mathbf{3 b}$.

During initial reactions while preparing $(S)$-1-azido-3-chloropropan-2-yl chloroformate 3a (by using molar excess triethylamine), formation of a major impurity was observed (>25\% by TLC), isolated (by column chromatography) and identified as ((S)-1-azido-3-chloropropan-2yloxycarbonyl)triethylammonium chloride 4 (Figure 3). The formation of impurity 4 could be explained by either of the following two reasons: (i) side reaction of $\mathbf{3 a}$ with $\mathrm{Et}_{3} \mathrm{~N}$, or (ii) reaction of excess phosgene with $\mathrm{Et}_{3} \mathrm{~N}$ resulting in formation of corresponding unstable complex 4a (Figure 3) which on further reaction with 2a gave impurity 4. The formation of $((S)$-1-azido-3chloropropan-2-yloxycarbonyl)triethylammonium chloride 4 was confirmed by its preparation starting from 3a on reaction with triethylamine in tetrahydrofuran. However, the side formation of $\mathbf{4}$ was restricted in the preparation of $\mathbf{3 a}$ by controlled addition of $\mathrm{Et}_{3} \mathrm{~N}$ and also by reducing the molar quantity. The impurity $\mathbf{4}$ formed is unstable and collapses, with elimination of ethyl chloride, to give a stable carbamoyl chloride derivative $\mathbf{4 b}$.
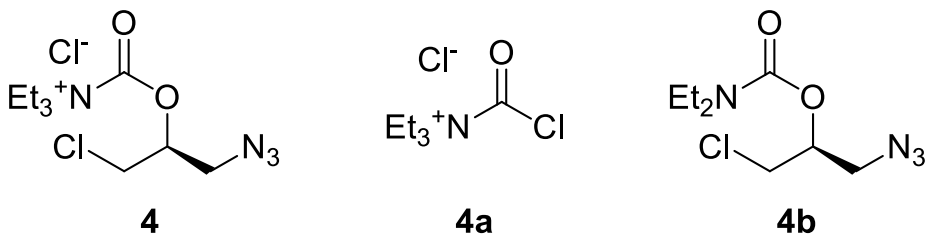

Figure 3. Chemical structures of $\mathbf{4 ,} \mathbf{4 a}$ and $\mathbf{4 b}$.

The chiral synthon 3a can be derivatized on both ends to develop new oxazolidinone antibacterial analogs as well as monoamine oxidase-B (MAO-B) inhibitors used in the treatment of Parkinson's disease. ${ }^{21}$ The chlorocarbonyl functionality in $\mathbf{3 a}$ and $\mathbf{3 b}$ can be converted to either carbamate or 2-oxazolidinone by reaction with amines. ${ }^{20}$ The azide functionality in 3a provides the required site for preparing different analogues of the oxazolidinone. The azide functionality can also be converted to carbamates, ureas, thiocarbamates and thioureas via iminophosphorane $^{22}$ and isocyanate or thiocyanate ${ }^{23}$ intermediates, respectively. Many 
established procedures are available for reductive conversion of azides to acetamides ${ }^{24}$ and carbamates. ${ }^{25}$

The utility of chiral synthons $\mathbf{3 a}$ and $\mathbf{3 b}$ has been exemplified by synthesizing Linezolid as shown in Scheme 2. The 2-oxazolidinone ring was constructed expeditiously by using chlorocarbonyl group in chloroformate $\mathbf{3}$ in a one-pot two step sequence. Accordingly, either $\mathbf{3 a}$ or $\mathbf{3 b}$ was treated with 3-fluoro-4-morpholinobenzenamine using molar excess $\mathrm{K}_{2} \mathrm{CO}_{3}$ in acetone resulting in corresponding 2-oxazolidinone $\mathbf{6}$. This reaction proceeded via the carbamate $\mathbf{5}$ and the reaction mixture was maintained under reaction conditions until the completion of $\mathbf{3}$ as well as $\mathbf{5}$. Initially, the carbamate $\mathbf{5 a}$ was isolated exclusively using triethylamine or molar equivalent $\mathrm{K}_{2} \mathrm{CO}_{3}$ in dichloromethane. In these conditions no formation of $\mathbf{6 a}$ was observed. As a summary, we developed a facile condition for the one-pot construction of 2-oxazolidinone ring (via carbamate) by the reaction of $\mathbf{3}$ with $\mathrm{K}_{2} \mathrm{CO}_{3}$ in acetone. Finally, the compound $\mathbf{6}$ was converted to Linezolid by reported conditions. ${ }^{12,15}$ The enantiomeric purity of Linezolid was readily assessed by chiral HPLC (Chiralpak ASH) and was found to be $99.9 \%$. This was confirmed by comparing the chromatogram of the Linezolid to that of racemic Linezolid synthesized starting from racemic epichlorohydrin.

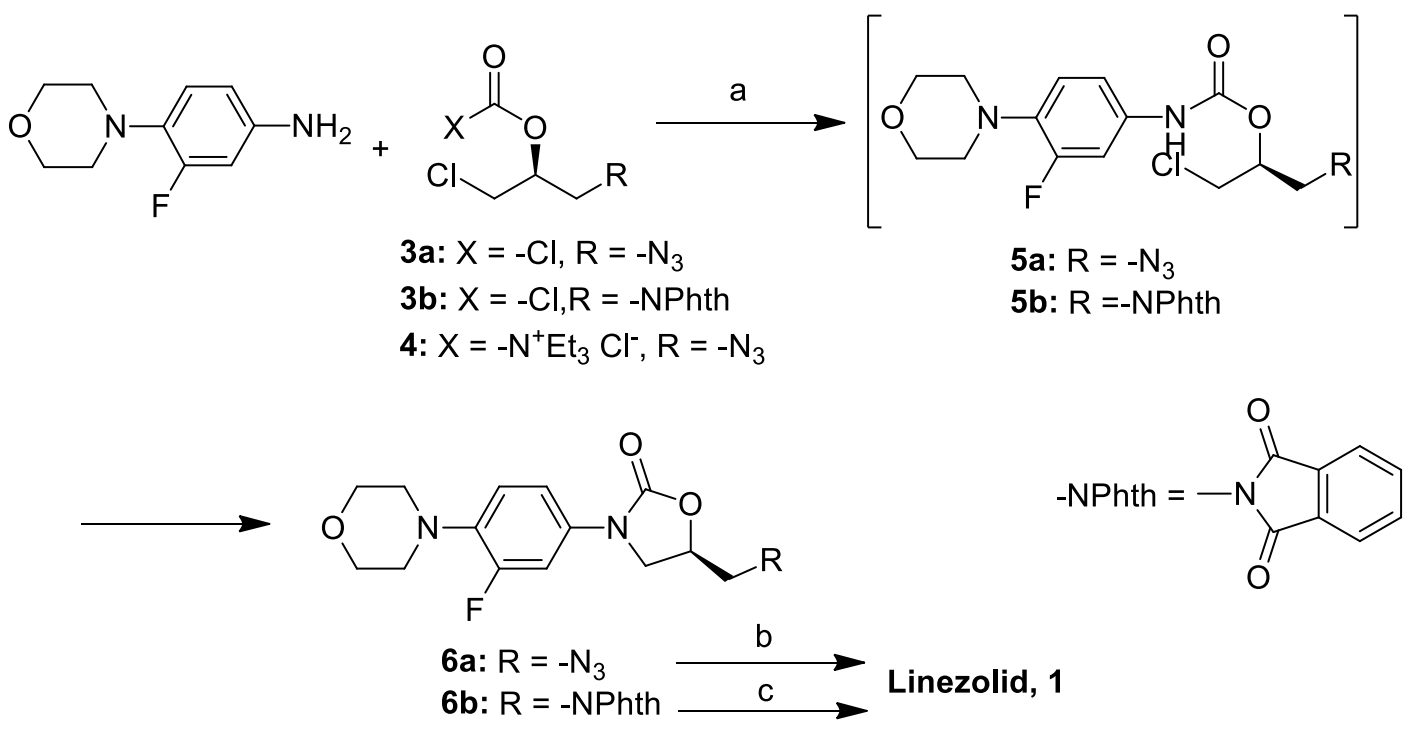

Reagents and conditions: (a) $\mathrm{K}_{2} \mathrm{CO}_{3}$, Acetone, r.t., overnight, 82-86\%; (b) $\mathrm{H}_{2}, \mathrm{Pd} / \mathrm{C}, \mathrm{Ac}_{2} \mathrm{O}, \mathrm{MeOH}, 20$ psi, r.t., 3 h, 85\%; (c) (i) Hydrazine hydrate, $\mathrm{MeOH}$, reflux, 1 h; (ii) $\mathrm{Ac}_{2} \mathrm{O}$, Toluene, r.t., 1 h, $70 \%$.

Scheme 2. Synthesis of Linezolid starting from either (S)-1-azido-3-chloropropan-2-yl chloroformate 3a or (S)-1-phthalimido-3-chloropropan-2-yl chloroformate $\mathbf{3 b}$.

Moreover, impurity 4 was not traceable in the initial reaction of $3 \mathbf{a}$ (contains $~ 25 \%$ of $\mathbf{4}$ ) with 3-fluoro-4-morpholinobenzenamine while synthesizing $(R)$-6a. In order to understand the further conversion of $\mathbf{4}$, a reaction was performed on chemically pure 4 with $\mathrm{K}_{2} \mathrm{CO}_{3}$ in acetone at room 
temperature which also resulted in the formation of $(R)-\mathbf{6 a}$. However, the reactivity of $\mathbf{4}$ with $\mathrm{ArNH}_{2}$ is quite low when compared to $(S)$-1-azido-3-chloropropan-2-yl chloroformate $\mathbf{3 a}$ and $\mathbf{3 b}$.

Using either (S)-1-azido-3-chloropropan-2-yl chloroformate 3a or $(S)$-phthalimido-3-chloro propan-2-yl chloroformate $\mathbf{3 b}$ as a starting material, we avoided the usage of $n$-BuLi, LDA, $\mathrm{LiO} t \mathrm{Bu}$ or cryogenic conditions and also increased the efficiency and atom economy of process during formation of 2-oxazolidinone in comparison to classical methods.

\section{Conclusions}

In summary, we describe herein the synthesis of novel chiral synthons, $(S)$-1-azido-3chloropropan-2-yl chloroformate 3a and $(S)$-phthalimido-3-chloropropan-2-yl chloroformate $\mathbf{3 b}$ which are precursors for further transformations into potential 2-oxazolidinone antibacterial agents. By using these chiral synthons, an efficient method has been demonstrated for 2oxazolidinone ring construction in a one-pot two step sequence via the corresponding carbamate. The applicability of this approach was shown by the synthesis of Linezolid. The application of this strategy to develop a series of 2-oxazolidinone analogues where the morpholine moiety of Linezolid could be replaced with new heterobicyclic systems ${ }^{17 \mathrm{~b}}$ is currently underway in our laboratory.

\section{Experimental Section}

General. All reagents and solvents employed were of commercial grade and were used as such, unless otherwise specified. Reaction flasks were oven-dried at $200^{\circ} \mathrm{C}$, flame-dried and flushed with dry nitrogen prior to use. All moisture and air-sensitive reactions were carried out under an atmosphere of dry nitrogen. TLC was performed on Kieselgel $60 \mathrm{~F}_{254}$ silica-coated aluminium plates (Merck) and visualized by using either UV light $(\lambda=254 \mathrm{~nm})$ or by spraying with a solution of ninhydrin or $\mathrm{KMnO}_{4}$. Organic extracts were dried over anhydrous $\mathrm{Na}_{2} \mathrm{SO}_{4}$. Flash column chromatography was performed using Kieselgel 60 brand silica gel (230-400 mesh). The melting points were determined in an open capillary tube using a Büchi B-540 melting point instrument and were uncorrected. Optical rotations were measured on an Autopol V, serial number 80455 (manufactured by Rudolph Research Analytical, Hackettstown, NJ, USA) at the sodium D line $(589 \mathrm{~nm})$ and are reported as follows: $[\alpha]^{{ }^{\circ} \mathrm{C}}{ }_{\mathrm{D}}$ (concentration in $\mathrm{g} / 100 \mathrm{~mL}$, solvent). The IR spectra were obtained on a Nicolet 380 FT-IR instrument (neat for liquids and as $\mathrm{KBr}$ pellets for solids). NMR spectra were recorded with a Varian $300 \mathrm{MHz}$ Mercury Plus Spectrometer at $300 \mathrm{MHz}\left({ }^{1} \mathrm{H}\right)$ and at $75 \mathrm{MHz}\left({ }^{13} \mathrm{C}\right)$. Chemical shifts were given in ppm relative to trimethylsilane (TMS). Data are reported as follows: s, singlet; d, doublet; t, triplet; q, quartet; qn, quintuplet; m, multiplet; and br, broad. Mass spectra were recorded on Waters Quattro Premier XE triple quadrupole spectrometer using either electrospray ionization (ESI) or 
atmospheric pressure chemical ionization (APCI) technique. The chromatographic system used for the chiral HPLC studies consisted of a Shimadzu LC-10AT HPLC system equipped with a Shimadzu SPD-10A UV absorbance detector, with the wavelength set to $240 \mathrm{~nm}$. Injections were made using an auto sampler Model Shimadzu SIL-20AC. Separation of the enantiomers of Linezolid were performed using a Chiralpak ASH column of dimensions $250 \times 4.6 \times 5.0 \mathrm{~mm}$. The column was fitted in a column oven Model Shimadzu CTO-10AS. UV absorbance $(\lambda=240$ $\mathrm{nm}$ ) chromatograms were recorded using an Advanced Computer Interface equipped with Chromatography Automation software Shimadzu CLASS-VP version 6.14 SP1. The isocratic mobile phase was a 60:40:0.1 (v/v) mixture of $n$-hexane : ethanol : diethylamine. The flow rate was $1.0 \mathrm{~mL} \mathrm{~min}^{-1}$ (Run time - $20 \mathrm{~min}$ ).

Synthetic procedure for $(\boldsymbol{S})$-1-Azido-3-chloropropan-2-ol (2a). (S)-Epichlorohydrin (10 g, $0.108 \mathrm{~mol}$ ) was dissolved in an aqueous solution of sodium azide ( $36.5 \mathrm{~g}, 0.561 \mathrm{~mol}$ in $100 \mathrm{~mL})$, acetic acid $(100 \mathrm{~mL})$ then added and the resulting solution was stirred for $5 \mathrm{~h}$ at ambient temperature. The reaction mixture was extracted with EtOAc $(3 \times 50 \mathrm{~mL})$ and the combined organic layer was washed with saturated $\mathrm{NaHCO}_{3}$ solution followed by water. The organics were dried over anhydrous $\mathrm{Na}_{2} \mathrm{SO}_{4}$ and evacuated. The obtained crude compound was purified by column chromatography (97:3 $n$-hexane-EtOAc) to afford $(S)$-1-azido-3-chloropropan-2-ol, 2a as a pale yellow thick liquid $(11.7 \mathrm{~g})$. Yield $80 \%,[\alpha]^{20}{ }_{\mathrm{D}}-0.77^{\circ}\left(c 1, \mathrm{CHCl}_{3}\right)$; IR (neat): $v 3436$ $(\mathrm{OH}), 2109\left(\mathrm{~N}_{3}\right) \mathrm{cm}^{-1} ;{ }^{1} \mathrm{H}$ NMR $\left(\mathrm{CDCl}_{3}\right): \delta 2.44$ (br s, 1H, -OH, $\mathrm{D}_{2} \mathrm{O}$ exchangeable), 3.48-3.64 $(\mathrm{m}, 4 \mathrm{H}), 4.0(\mathrm{~m}, 1 \mathrm{H})$; APCI-MS $\left(\mathrm{C}_{3} \mathrm{H}_{6} \mathrm{ClN}_{3} \mathrm{O}\right): \mathrm{m} / z(\%) 136\left(100, \mathrm{M}^{+}+1\right)$.

2-((S)-3-Chloro-2-hydroxypropyl)isoindoline-1,3-dione (2b). To a stirred solution of $(S)$ epichlorohydrin $(8.0 \mathrm{~g}, 0.086 \mathrm{~mol})$, phthalimide $(12.72 \mathrm{~g}, 0.086 \mathrm{~mol})$ and isopropanol $(60 \mathrm{~mL})$, was added catalytic amount of potassium carbonate $(1.1 \mathrm{~g}, 0.008 \mathrm{~mol})$ at room temperature. The reaction mixture was heated to reflux and maintained at reflux temperature for 5-7 $\mathrm{h}$. The progress of the reaction was monitored by TLC. After completion of the reaction, reaction mixture was cooled to room temperature and solvent was removed under reduced pressure at below $40{ }^{\circ} \mathrm{C}$. The obtained residue was triturated with water, filtered and solid was slurry washed with water. The obtained solid was unloaded and dried at $60{ }^{\circ} \mathrm{C}$ under reduced pressure to give 2-((S)-3-chloro-2-hydroxypropyl)isoindoline-1,3-dione $\mathbf{2 b}$ as a white solid (15.5 g). Yield $75 \%, \operatorname{mp} 95-96{ }^{\circ} \mathrm{C},[\alpha]^{20} \mathrm{D}-32.5^{\circ}\left(c 0.712, \mathrm{CHCl}_{3}\right)$; IR $(\mathrm{KBr}): v 3463(\mathrm{OH}), 1692(\mathrm{C}=\mathrm{O}) \mathrm{cm}^{-1}$; ${ }^{1} \mathrm{H}$ NMR $\left(\mathrm{CDCl}_{3}\right): \delta$ 2.82-2.84 (d, 1H, -OH, D $2 \mathrm{O}$ exchangeable), 3.59-3.71 (m, 2H), 3.85-4.01 $(\mathrm{m}, 2 \mathrm{H}), 4.15-4.21(\mathrm{~m}, 1 \mathrm{H}), 7.72-7.78(\mathrm{~m}, 2 \mathrm{H}), 7.85-7.89(\mathrm{~m}, 2 \mathrm{H}) ;{ }^{13} \mathrm{C} \mathrm{NMR}\left(\mathrm{CDCl}_{3}\right): \delta 41.5$, 47.2, 69.64, 123.5, 131.8, 134.2, 168.6; ESI-MS $\left(\mathrm{C}_{11} \mathrm{H}_{10} \mathrm{ClNO}_{3}\right): \mathrm{m} / z(\%) 240\left(100, \mathrm{M}^{+}+1\right)$.

(S)-3-Azido-1-chloropropan-2-yl chloroformate (3a). $\mathrm{Et}_{3} \mathrm{~N}(10.1 \mathrm{~g}, 1.0 \mathrm{~mol})$ rinsed with tetrahydrofuran $(10 \mathrm{~mL})$ is slowly added to a solution of $(S)$-1-azido-3-chloropropan-2-ol 2a (9.0 $\mathrm{g}, 0.066 \mathrm{~mol})$, triphosgene $(9.8 \mathrm{~g}, 0.033 \mathrm{~mol})$ and tetrahydrofuran $(80 \mathrm{~mL})$ at $0{ }^{\circ} \mathrm{C}$ under inert atmosphere $\left(\mathrm{N}_{2}\right)$. After completion of addition, the reaction mixture was allowed to room temperature and stirred for 2-3 h. After completion of reaction (TLC), the reaction mixture was quenched with water and extracted with $\mathrm{CH}_{2} \mathrm{Cl}_{2}(3 \times 75 \mathrm{~mL})$. The organics were dried over 
anhydrous $\mathrm{Na}_{2} \mathrm{SO}_{4}$ and evacuated. The crude was purified by column chromatography (99:1 $n$ hexane-EtOAc) to afford the pure (S)-1-azido-3-chloropropan-2-yl chloroformate 3a as a pale yellow syrupy liquid $(9.5 \mathrm{~g})$. Yield $72 \%,[\alpha]^{20}{ }_{\mathrm{D}}-3.3^{\circ}\left(c 1, \mathrm{CHCl}_{3}\right)$, IR (neat): $v 2109\left(\mathrm{~N}_{3}\right), 1777$ $(\mathrm{C}=\mathrm{O}) \mathrm{cm}^{-1} ;{ }^{1} \mathrm{H}$ NMR $\left(\mathrm{CDCl}_{3}\right): \delta 3.68-3.82(\mathrm{~m}, 4 \mathrm{H}), 5.08-5.15(\mathrm{~m}, 1 \mathrm{H}) ;{ }^{13} \mathrm{C} \mathrm{NMR}\left(\mathrm{CDCl}_{3}\right): \delta$ 41.20, 50.35, 78.58, 150.33; ESI-MS $\left(\mathrm{C}_{4} \mathrm{H}_{5} \mathrm{Cl}_{2} \mathrm{~N}_{3} \mathrm{O}_{2}\right): \mathrm{m} / z$ (\%) 161 (100) $196\left(40, \mathrm{M}^{+}-1\right), 198$ $\left(50, \mathrm{M}^{+}+1\right), 200\left(30, \mathrm{M}^{+}+3\right)$. Elemental Anal.calcd for $\mathrm{C}_{4} \mathrm{H}_{5} \mathrm{Cl}_{2} \mathrm{~N}_{3} \mathrm{O}_{2}: \mathrm{C}, 24.26 ; \mathrm{H}, 2.55 ; \mathrm{N}$, 21.22. Found: C, 23.79; H, 2.35; N, 20.93.

(S)-3-Chloro-1-(1,3-dioxoisoindolin-2-yl)propan-2-yl chloroformate (3b). Compound 3b was prepared by using the method described for the preparation of 3a. This compound was purified using isopropanol and obtained as a white colored solid. Yield $89 \%, \mathrm{mp} 90-93^{\circ} \mathrm{C},[\alpha]^{20} \mathrm{D}-4.03^{\circ}$ (c $\left.1, \mathrm{CHCl}_{3}\right)$, IR $(\mathrm{KBr}): v 1771(\mathrm{C}=\mathrm{O}), 1715(\mathrm{C}=\mathrm{O}) \mathrm{cm}^{-1} ;{ }^{1} \mathrm{H}$ NMR $\left(\mathrm{CDCl}_{3}\right): \delta$ 3.66-3.72 (m, $1 \mathrm{H}), 3.79-3.84(\mathrm{~m}, 1 \mathrm{H}), 4.05-4.11(\mathrm{~m}, 2 \mathrm{H}), 5.30-5.36(\mathrm{~m}, 1 \mathrm{H}), 7.74-7.80(\mathrm{~m}, 1 \mathrm{H}), 7.88-7.93(\mathrm{~m}$, $1 \mathrm{H}) ;{ }^{13} \mathrm{C} \mathrm{NMR}\left(\mathrm{CDCl}_{3}\right): \delta 38.3,42.4,78.5,123.5,123.7,131.5,134.2,134.4,150.5,167.8$; ESIMS $\left(\mathrm{C}_{12} \mathrm{H}_{9} \mathrm{Cl}_{2} \mathrm{NO}_{4}\right): m / z(\%) 302\left(\mathrm{M}^{+}+1\right)$. Elemental Anal.calcd for $\mathrm{C}_{12} \mathrm{H}_{9} \mathrm{Cl}_{2} \mathrm{NO}_{4}: \mathrm{C}, 47.71 ; \mathrm{H}$, 3.00 ; N, 4.64. Found: C, 47.69; H, 2.95; N, 4.54 .

\section{((S)-1-Azido-3-chloropropan-2-yloxycarbonyl)triethylammonium chloride (4)}

(a) From (S)-1-azido-3-chloropropan-2-ol (2a). $\mathrm{Et}_{3} \mathrm{~N}(3.95 \mathrm{~g}, 0.039 \mathrm{~mol})$ rinsed with tetrahydrofuran $(5 \mathrm{~mL})$ is slowly added to a solution of $(S)$-1-azido-3-chloropropan-2-ol 2a (2.0 $\mathrm{g}, 0.015 \mathrm{~mol})$, triphosgene $(2.2 \mathrm{~g}, 0.007 \mathrm{~mol})$ and tetrahydrofuran $(40 \mathrm{~mL})$ at below $10{ }^{\circ} \mathrm{C}$ under inert atmosphere $\left(\mathrm{N}_{2}\right)$. After completion of addition, the reaction mixture was allowed to room temperature and stirred for 5-6 h. After completion of reaction (TLC), the reaction mixture was diluted with water and extracted with $\mathrm{CH}_{2} \mathrm{Cl}_{2}(3 \times 40 \mathrm{~mL})$. The organics were dried over anhydrous $\mathrm{Na}_{2} \mathrm{SO}_{4}$ and evacuated to afford 4 as a pale yellow colored thick liquid (3.7 g). Yield $83 \%$.

(b) From (S)-3-azido-1-chloropropan-2-yl chloroformate (3a). $\mathrm{Et}_{3} \mathrm{~N}(0.77 \mathrm{~g}, 0.008 \mathrm{~mol})$ rinsed with tetrahydrofuran $(2.5 \mathrm{~mL})$ is slowly added to a solution of $(S)$-1-azido-3chloropropan-2-yl chloroformate 3a $(1.2 \mathrm{~g}, 0.006 \mathrm{~mol})$ and tetrahydrofuran $(15 \mathrm{~mL})$ at ambient temperature and stirred for 2-3 $\mathrm{h}$. After completion of reaction (TLC), the reaction mixture was diluted with water and extracted with $\mathrm{CH}_{2} \mathrm{Cl}_{2}(3 \times 40 \mathrm{~mL})$. The organics were dried over anhydrous $\mathrm{Na}_{2} \mathrm{SO}_{4}$ and evacuated to afford 4 as a pale yellow colored thick liquid (1.6 g). Yield $88 \%,[\alpha]^{20} \mathrm{D}-9.3^{\circ}\left(c 1, \mathrm{CHCl}_{3}\right), \mathrm{IR}$ (neat): $v 2974\left(\mathrm{NEt}_{3}\right), 2107\left(\mathrm{~N}_{3}\right), 1755(\mathrm{C}=\mathrm{O}), 1703,1443$ $\mathrm{cm}^{-1} ;{ }^{1} \mathrm{H}$ NMR $\left(\mathrm{CDCl}_{3}\right): \delta 1.13-1.18(\mathrm{t}, 9 \mathrm{H}), 3.21-3.34(\mathrm{~m}, 6 \mathrm{H}), 3.58-3.62(\mathrm{~m}, 2 \mathrm{H}), 3.66-3.72(\mathrm{~m}$, $2 \mathrm{H}), 5.00-5.08(\mathrm{~m}, 1 \mathrm{H})$.

(S)-1-Azido-3-chloropropan-2-yl diethylcarbamate (4b). Compound 4 formed in the above procedure is found to be unstable and collapses (after a week on standing at room temperature), with elimination of ethyl chloride, to give a stable carbamoyl chloride derivative $\mathbf{4 b} .{ }^{1} \mathrm{H}$ NMR $\left(\mathrm{CDCl}_{3}\right): \delta 1.13-1.18(\mathrm{t}, 6 \mathrm{H}), 3.30(\mathrm{~m}, 4 \mathrm{H}), 3.58-3.60(\mathrm{~m}, 2 \mathrm{H}), 3.67-3.76(\mathrm{~m}, 2 \mathrm{H}), 5.03-5.06(\mathrm{~m}$, $1 \mathrm{H}) ;{ }^{13} \mathrm{C}$ NMR $\left(\mathrm{CDCl}_{3}\right): \delta 13.25,13.87,41.40,42.03,42.81,51.18,71.88,154.20$; HRMS (ESI) found: $235.1002,\left[\mathrm{C}_{8} \mathrm{H}_{15} \mathrm{ClN}_{4} \mathrm{O}_{2}+\mathrm{H}\right]^{+}$calcd: 235.0962 . 
(S)-3-Azido-1-chloropropan-2-yl 3-fluoro-4-morpholinophenylcarbamate (5a). To a stirred solution of (S)-3-azido-1-chloropropan-2-yl chloroformate, 3a (4.0 g, 0.02 mol), 3-fluoro-4morpholinobenzenamine $(3.33 \mathrm{~g}, 0.017 \mathrm{~mol})$ and dichloromethane $(40 \mathrm{~mL})$ was added potassium carbonate $(2.77 \mathrm{~g}, 0.02 \mathrm{~mol})$ at room temperature. The mixture was stirred at room temperature for 4-5 $\mathrm{h}$ and reaction completion was montitored by TLC. The reaction mixture was filtered to remove solids and washed with $\mathrm{CH}_{2} \mathrm{Cl}_{2}$. The combined filtrate was washed with water, dried over anhydrous $\mathrm{Na}_{2} \mathrm{SO}_{4}$ and evacuated to give $(S)$-3-azido-1-chloropropan-2-yl 3-fluoro-4morpholinophenylcarbamate 5a as a brown colored gummy solid (5.2 g). This compound was used in the next step with out further purification. Yield 85\%, IR (neat): v $3304(\mathrm{NH}) 2106\left(\mathrm{~N}_{3}\right)$, $1709(\mathrm{C}=\mathrm{O}) \mathrm{cm}^{-1} ;{ }^{1} \mathrm{H}$ NMR $\left(\mathrm{CDCl}_{3}\right): \delta 3.03-3.06(\mathrm{t}, 4 \mathrm{H}), 3.63-3.64(\mathrm{~d}, 2 \mathrm{H}), 3.73-3.75(\mathrm{~m}, 2 \mathrm{H})$, 3.85-3.88 (t, 4H), 5.08-5.15 (m, 1H), $6.73($ br s, 1H), 6.86-6.92 (t, 1H), 6.98-7.01 (t, 1H), 7.26$7.30(\mathrm{~d}, 1 \mathrm{H})$; ESI-MS $\left(\mathrm{C}_{14} \mathrm{H}_{17} \mathrm{ClFN}_{5} \mathrm{O}_{3}\right): \mathrm{m} / z(\%) 358\left(100, \mathrm{M}^{+}+1\right) 360\left(55, \mathrm{M}^{+}+3\right), 223(75)$.

(S)-3-Chloro-1-(1,3-dioxoisoindolin-2-yl)propan-2-yl 3-fluoro-4-morpholinophenylcarbamate (5b). Compound 5b was prepared by using the method described for the preparation of 5a. Yield 86\%, mp. 200-202 ${ }^{\circ} \mathrm{C}$; IR (KBr): v $3302(\mathrm{NH}), 3123$ (Ar-H), 2961 (C-H), 1648 (C=O), 1219 (C$\mathrm{O}-\mathrm{C}) \mathrm{cm}^{-1} ;{ }^{1} \mathrm{H}$ NMR $\left(\mathrm{CDCl}_{3}\right): \delta 3.00-3.03(\mathrm{t}, 4 \mathrm{H}), 3.73-3.74(\mathrm{dd}, 1 \mathrm{H}), 3.80-3.82(\mathrm{dd}, 1 \mathrm{H}), 3.84-$ $3.87(\mathrm{~m}, 4 \mathrm{H}), 3.99-4.00(\mathrm{dd}, 1 \mathrm{H}), 4.09-4.12(\mathrm{dd}, 1 \mathrm{H}), 5.30-5.33(\mathrm{~m}, 1 \mathrm{H}), 6.66(\mathrm{~s}, 1 \mathrm{H},-\mathrm{NH}), 6.84-$ $6.90(\mathrm{~m}, 2 \mathrm{H}), 7.20-7.21(\mathrm{~d}, 1 \mathrm{H}), 7.72-7.75(\mathrm{~m}, 2 \mathrm{H}), 7.85-7.88(\mathrm{~m}, 2 \mathrm{H})$; ESI-MS $\left(\mathrm{C}_{22} \mathrm{H}_{21} \mathrm{ClFN}_{3} \mathrm{O}_{5}\right)$ : $\mathrm{m} / \mathrm{z}(\%) 462\left(100, \mathrm{M}^{+}+1\right)$.

\section{(R)-5-(Azidomethyl)-3-(3-fluoro-4-morpholinophenyl)oxazolidin-2-one (6a)}

(a) From $(S)$-carbamate (5a). To a stirred solution of $(S)$-3-azido-1-chloropropan-2-yl 3-fluoro4-morpholinophenylcarbamate $5 \mathbf{a}(5.0 \mathrm{~g}, 0.014 \mathrm{~mol})$ and acetone $(25 \mathrm{~mL})$ was added potassium carbonate $(2.34 \mathrm{~g}, 0.017 \mathrm{~mol})$ at room temperature. The mixture was stirred at room temperature for $8 \mathrm{~h}$. After completion of reaction (TLC), solvent was removed under reduced pressure and the obtained residue was diluted with water. The aqueous was extracted with $\mathrm{CH}_{2} \mathrm{Cl}_{2}(3 \times 50$ $\mathrm{mL}$ ). The organics were washed with saturated $\mathrm{NaCl}$ solution, dried over anhydrous $\mathrm{Na}_{2} \mathrm{SO}_{4}$ and evacuated. The crude compound was triturated with $n$-hexane (15 mL) to give $(R)-5$ (azidomethyl)-3-(3-fluoro-4-morpholinophenyl) oxazolidin-2-one, 6a as a off-white solid (3.7 g) in $83 \%$ yield.

(b) One-pot procedure from $(S)$-3-azido-1-chloropropan-2-yl chloroformate (3a). To a stirred solution of (S)-3-azido-1-chloropropan-2-yl chloroformate 3a (5.0 g, $0.025 \mathrm{~mol})$, 3fluoro-4-morpholinobenzenamine $(4.12 \mathrm{~g}, 0.021 \mathrm{~mol})$ and acetone $(50 \mathrm{~mL})$ was added potassium carbonate $(12.2 \mathrm{~g}, 0.088 \mathrm{~mol})$ at room temperature and stirred overnight. After completion of reaction (TLC), solvent was removed under reduced pressure and the obtained residue was diluted with water. The aqueous was extracted with $\mathrm{CH}_{2} \mathrm{Cl}_{2}(3 \times 50 \mathrm{~mL})$. The organics were washed with saturated $\mathrm{NaCl}$ solution, dried over anhydrous $\mathrm{Na}_{2} \mathrm{SO}_{4}$ and evacuated. The crude compound was triturated with $n$-hexane $(15 \mathrm{~mL})$ to give $\mathbf{6 a}$ as a off-white colored solid $(5.5 \mathrm{~g})$. Yield 82\%, mp 97-100 ${ }^{\circ} \mathrm{C}$, (lit. ${ }^{26}$ 102.5-103.5 ${ }^{\circ} \mathrm{C}$ ); IR (KBr): v 3109 (Ar-H), 2965 (C-H), 2103 $\left(\mathrm{N}_{3}\right) 1744(\mathrm{C}=\mathrm{O}) \mathrm{cm}^{-1} ;{ }^{1} \mathrm{H}$ NMR $\left(\mathrm{CDCl}_{3}\right): \delta 3.05-3.07(\mathrm{t}, 4 \mathrm{H}), 3.57-3.62(\mathrm{dd}, 1 \mathrm{H}), 3.68-3.74(\mathrm{dd}$, 
$1 \mathrm{H}), 3.80-3.88(\mathrm{~m}, 5 \mathrm{H}), 4.03-4.09(\mathrm{t}, 1 \mathrm{H}), 4.77-4.79(\mathrm{~m}, 1 \mathrm{H}), 6.91-6.97(\mathrm{t}, 1 \mathrm{H}), 7.12-7.15(\mathrm{~d}$, $1 \mathrm{H}), 7.43-7.47(\mathrm{~d}, 1 \mathrm{H})$; ESI-MS $\left(\mathrm{C}_{14} \mathrm{H}_{16} \mathrm{FN}_{5} \mathrm{O}_{3}\right): \mathrm{m} / z(\%) 322.1\left(100, \mathrm{M}^{+}+1\right), 296$ (40).

\section{2-(((S)-3-(3-Fluoro-4-morpholinophenyl)-2-oxooxazolidin-5-yl)methyl)isoindoline-1,3-dione}

(6b). Compound $\mathbf{6 b}$ was prepared by using the method described for the preparation of $\mathbf{6 a}$. Yield 86\%, mp 204-206 ${ }^{\circ} \mathrm{C}$; IR (KBr): v 3099 (Ar-H), 2962 (C-H), 1752 (C=O), 1711 (C=O), 1218 $(\mathrm{C}-\mathrm{O}-\mathrm{C}) \mathrm{cm}^{-1}$; ${ }^{1} \mathrm{H}$ NMR $\left(\mathrm{CDCl}_{3}\right): \delta 3.03-3.07(\mathrm{t}, 4 \mathrm{H}), 3.86-3.89(\mathrm{t}, 4 \mathrm{H}), 3.94-4.19(\mathrm{~m}, 4 \mathrm{H}), 4.96-$ $5.00(\mathrm{~m}, 1 \mathrm{H}), 6.89-6.95(\mathrm{t}, 1 \mathrm{H}), 7.10-7.13(\mathrm{~d}, 1 \mathrm{H}), 7.39-7.45(\mathrm{~d}, 1 \mathrm{H}), 7.76-7.80(\mathrm{~m}, 2 \mathrm{H}), 7.87-$ $7.91(\mathrm{~m}, 2 \mathrm{H}) ;{ }^{13} \mathrm{C} \mathrm{NMR}\left(\mathrm{CDCl}_{3}\right): \delta 40.7,48.4,50.9,50.96,66.9,69.5,107.4,107.7,113.9$, $114.0,118.7,118.79,123.6,131.6,132.8,134.4,136.4,136.5,153.7,167.9$. ESI-MS $\left(\mathrm{C}_{22} \mathrm{H}_{20} \mathrm{FN}_{3} \mathrm{O}_{5}\right): m / z(\%) 426.2\left(100, \mathrm{M}^{+}+1\right)$.

$\boldsymbol{N}$-(((S)-3-(3-fluoro-4-morpholinophenyl)-2-oxooxazolidin-5-yl)methyl)acetamide 1 (Linezolid) 1 was prepared according to the method described in literature. ${ }^{12,15} \mathrm{Mp} 182-183{ }^{\circ} \mathrm{C}$, (lit. ${ }^{12 \mathrm{a}} 181.5$ $182.5^{\circ} \mathrm{C}$ ); enantiomeric purity $99.9 \%$ (by chiral HPLC); IR $(\mathrm{KBr}): v 3343(\mathrm{NH}), 3075(\mathrm{Ar}-\mathrm{H})$, $2967(\mathrm{CH}), 1741(\mathrm{C}=\mathrm{O}), 1660(\mathrm{C}=\mathrm{O}) \mathrm{cm}^{-1} ;{ }^{1} \mathrm{H}$ NMR $\left(\mathrm{CDCl}_{3}\right): \delta 2.03(\mathrm{~s}, 3 \mathrm{H}), 3.04-3.07(\mathrm{t}, 4 \mathrm{H})$, 3.56-3.77 (m, 3H), 3.86-3.89 (t, 4H), 4.00-4.06 (t, 1H), 4.74-4.79 (m, 1H), $5.96(\mathrm{~s}, 1 \mathrm{H}), 6.90$ $6.96(\mathrm{t}, 1 \mathrm{H}), 7.06-7.10(\mathrm{~d}, 1 \mathrm{H}), 7.43-7.48(\mathrm{~d}, 1 \mathrm{H}) .{ }^{13} \mathrm{C}$ NMR (DMSO- $\left.d_{6}\right): \delta 22.4,41.4,47.3,50.6$, $66.1,71.5,106.4,114.0,119.1,133.3,135.5,154.0,156.2,170.0 ;$ ESI-MS $\left(\mathrm{C}_{16} \mathrm{H}_{20} \mathrm{FN}_{3} \mathrm{O}_{4}\right): \mathrm{m} / z$ (\%) $338.18\left(100, \mathrm{M}^{+}+1\right)$.

\section{Acknowledgements}

Financial support from the Inogent Laboratories Private Limited (A GVK BIO Company) is gratefully acknowledged.

\section{References}

1. FDA talks paper. FDA approves ZYVOX, the first antimicrobial drug in a new class. Food and Drugs Administration, April 18, 2000.

2. Wallace, R. J. J.; Brown-Elliott, B. A.; Ward, S. C.; Crist, C. J.; Mann, L. B.; Wilson, R. W. Abstr. ICAAC 2001, 45, 764.

3. Peters, J.; Kondo, K.; Lee, R.; Lin, C.; Inderlied, C. J. Antimicrob. Chemother. 1995, 35 , 675.

4. Vardakas, K. Z.; Kioumis, I.; Falagas, M. E. Curr. Drug Metab. 2009, 10, 2.

5. Potoski, B. A.; Adams, J.; Clarke, L.; Shutt, K.; Linden, P. K.; Baxter, C.; Pasculle, A. W.; Capitano, B.; Peleg, A. Y.; Szabo, D.; Paterson, D. L. Clin. Infect. Dis. 2006, 43, 165. 
6. Toh, S. M.; Xiong, L.; Arias, C. A.; Villegas, M. V.; Lolans, K.; Quinn, J.; Mankin, A. S. Mol. Microbiol. 2007, 64, 1506.

7. Roehrig, S.; Straub, A.; Pohlmann, J.; Lampe, T.; Pernerstorfer, J.; Schlemmer, K.-H.; Reinemer, P.; Perzborn, E. J. Med. Chem. 2005, 48, 5900.

8. Kalia, V.; Miglani, R.; Purnapatre, K. P.; Mathur, T.; Singhal, S.; Khan, S.; Voleti, S. R.; Upadhyay, D. J.; Saini, K. S.; Rattan, A.; Raj, V. S. Antimicrob. Agents Chemother. 2009, $53,1427$.

9. Howe, R. A.; Wootton, M.; Noel, A. R.; Bowker, K. E.; Walsh, T. R.; MacGowan, A. P. Antimicrob. Agents Chemother. 2003, 47, 3651.

10. Livermore, D. M.; Mushtaq, S.; Warner, M.; Woodford, N. J. Antimicrob. Chemother. 2009, $63,713$.

11. Skripkin, E.; McConnell, T. S.; DeVito, J.; Lawrence, L.; Ippolito, J. A.; Duffy, E. M.; Sutcliffe, J.; Franceschi, F. Antimicrob. Agents Chemother. 2008, 52, 3550.

12. (a) Brickner, S. J.; Hutchinson, D. K.; Barbachyn, M. R.; Manninen, P. R.; Ulanowicz, D. A.; Garmon, S. A.; Grega, K. C.; Hendges, S. K.; Toops, D. S.; Ford, C. W.; Zurenko, G. E. J. Med. Chem. 1996, 39, 673. (b) Barbachyn, M. R.; Brickner, S. J.; Hutchinson, D. K. U.S. patent 5688792; 1997; Chem. Abstr. 1995, 123, 256742. (c) Dhananjay, G. S.; Nandu, B. B.; Avinash, V. N.; Kamlesh, D. S.; Anindya, S. B.; Tushar, A. N. PCT Int. Appl. 063505, 2009; Chem. Abstr. 2009, 150, 515152.

13. (a) Imbordino, R. J.; Perrault, W. R.; Reeder, M. R. PCT Int. Appl. 116284, 2007; Chem. Abstr. 2007, 147, 469356. (b) Pearlman, B. A.; Perrault, W. R.; Barbachyn, M. R.; Manninen, P. R.; Toops, D. S.; Houser, D. J.; Fleck, T. J. U.S. Patent 5837870, 1998; Chem. Abstr. 1998, 130, 25061. (c) Perrault, W. R.; Pearlman, B. A.; Godrej, D. B.; Jeganathan, A.; Yamagata, K.; Chen, J. J.; Lu, C. V.; Herrinton, P. M.; Gadwood, R. C.; Chan, L.; Lyster, M. A.; Maloney, M. T.; Moeslein, J. A.; Greene, M. L.; Barbachyn, M. R. Org. Proc. Res. Dev. 2003, 7, 533.

14. (a) Yu, D. S.; Huang, L.; Liang, H.; Gong, P. Chin. Chem. Lett. 2005, 16, 875. (b) Pearlman, B. A. PCT Int. Appl. 9924393, 1999; Chem. Abstr. 1999, 130, 338099. (c) Weigert, F. J. J. Org. Chem. 1973, 38, 1316.

15. (a) Wang, M.; Tong, H. CN patent 101220001, 2008. (b) Mohan Rao, D.; Krishna Reddy, P. PCT Int. Appl. 099353, 2005; Chem. Abstr. 2005, 143, 440395. (c) Mohan Rao, D.; Krishna Reddy, P. PCT Int. Appl. 008754, 2006; Chem. Abstr. 2006, 144, 170978.

16. Madhusudhan, G.; Om Reddy, G.; Ramanatham, J.; Dubey, P. K. Indian J. Chem. 2005, 44B, 1236.

17. (a) Madhusudhan, G.; Om Reddy, G.; Rajesh, T.; Ramanatham, J.; Dubey, P. K. Tetrahedron Lett. 2008, 49, 3060-3062. (b) Rajesh, T.; Narayana Rao, S. P.; Suresh, K. Madhusudhan, G.; Mukkanti, K. J. Hetercyclic Chem. 2010, 47, 1392. 
18. (a) Moran-Ramallal, R.; Liz, R.; Gotor, V. Org. Lett. 2008, 10, 1935. (b) Mallesham, B.; Rajesh, B. M.; Rajamohan Reddy, P.; Srinivas, D.; Sanjay, T. Org. Lett. 2003, 5, 963.

19. (a) Selvakumar, N.; Srinivas, D.; Manoj Kumar, K.; Sitaram Kumar, M.; Mamidi Rao, N. V. S.; Hemanth, S.; Chandrashekar, C.; Srinivasa Rao, B.; Mohammed Raheem, A.; Jagattaran D.; Javed I.; Raagopalan, R. J. Med. Chem. 2002, 45, 3953. (b) Tokuyama, R.; Takahashi, Y.; Tomita, Y.; Tsubouchi, M.; Yoshida, T.; Iwasaki, N.; Kado, N.; Okezaki, E.; Nagata, O. Chem. Pharm. Bull. 2001, 49, 353.

20. (a) Jones, J. I. J. Chem. Soc. 1957, 2735. (b) Shimizu, M.; Tanaka, E.; Yoshioka, H. A J. Chem. Soc., Chem. Commun. 1987, 136. (c) Sugiyama, S.; Morishita, K.; Ishii, K. Heterocycles 2001, 55, 353.

21. Wouters, J. Curr. Med. Chem. 1998, 5, 137 and references cited therein.

22. (a) Molina, P.; Vilaplana, M. J. Synthesis 1994, 1197. (b) Alvarez-Sarandes, R.; Peinador, C.; Quintela, J. M. Tetrahedron 2001, 57, 5413 and references cited therein.

23. Molina, P.; Alaarin, M.; Vidal, A. Tetrahedron 1990, 46, 1063.

24. Barua, A.; Bez, G.; Barua, N. C. Synlett 1999, 553. (b) Rosen, T.; Lico, I. M.; Chu. D. T. W. J. Org. Chem. 1988, 53, 1580.

25. (a) Kotsuki, H.; Ohishi, T.; Araki, T. Tetrahedron Lett. 1997, 38, 2129. (b) Chandrasekhar, S.; Chandraiah, L.; Rai Reddy, Ch.; Venkat Reddy, M. Chem. Lett. 2000, 780.

26. Zhang, X.; Chen, W.; Li, C.; Wu, X. J. Chem. Res. Synop. 2009, 12, 739. 